\title{
Functional and nutritional health benefit of cold-pressed oils: a review
}

\author{
S Chandra, M Kumar, P Dwivedi \& LP Shinde
}

\section{Journal of}

Journal of Agriculture and Ecology

ISSN: 2456-9410

Volume: 9

Journal of Agriculture and Ecology (2020) 9: 21-29 http://doi.org/10.53911/JAE.2020.9102

\section{Agriculture and}

कृषि एवं शुक्क पारिस्थितिकी अनुसंधान सासाइटी

Society for Agriculture and Arid Ecology Research Bikaner (Rajasthan) INDIA-334006 Website: www.sagerorg. in 


\title{
Functional and nutritional health benefit of cold-pressed oils: a review
}

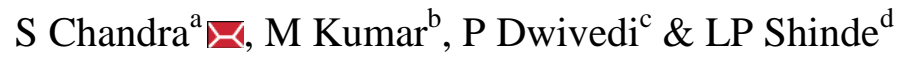 \\ ${ }^{a}$ Chemistry Division, Forensic Science Laboratory, Rohini, New Delhi, India \\ ${ }^{b}$ Department of Chemistry, Vardhman College, Bijnaur,UP, India \\ ${ }^{c}$ Department of $R \& D$, Nutrilis Foods, Noida, UP, India \\ ${ }^{d}$ Department of Chemistry, NES Science College, Nanded, Maharashtra, India \\ Corresponding author: S Chandra,E-mail: info@chicoree.in
}

Article Info
Article history
Received: 25 December 2019
Accepted: 20 May 2020
Available online: 30 June 2020

Key Words: Cold pressed oil, Functional benefits, Nutritional benefits, bioactive compounds.

\begin{abstract}
Kachi ghani or cold pressed it means pressing the oil grains with force and oil is extracting. Its processed at lower temperature does not alter the properties of the oil which contains a higher phenolic content, flavour, aroma and nutritional value. The nutritionally valuable bioactive components of cold-pressed oils were presented such as: tocopherols, sterols, carotenoids and phospholipids with oxidizing properties partly removed from refined oils or destroyed during the industrial refining. Cold pressed oil does not contain trans fatty acids and are naturally cholesterol, it has great importance for cooking and skin care requirements. In the present study it was emphasized on functional food and nutritional characteristics of cold-pressed oils and the method of its extraction, factors influencing the quality attributes of the obtained oils were also discussed.
\end{abstract}

Copyright (C2020 Chandra et al., This is an open access article published under the terms of the Creative Commons Attribution License, which permits unrestricted use, distribution, and reproduction in any medium, provided the original work is properly cited.

Preferred citation: Chandra S, Kumar M, Dwivedi P \& Shinde LP. 2020. Functional and nutritional health benefit of cold-pressed oils: a review. Journal of Agriculture and Ecology, 9: 21-29; http://doi.org/10.53911/JAE.2020.9102.

\section{Introduction}

In recent years, the consumers are paying more and more attention to those aspects of their life which improves its quality. Therefore, the diet, in addition to the way and conditions of life, is one of the key factors influencing human health and wellbeing. The consumers for fear of chemical remnants in the food and those environmentally-conscious choose the oils unaffected by drastic thermal treatment.
Recently, an increase in the consumption of cold-pressed edible oils has been observed. In terms of nutritional values, these oils are more beneficial than the refined oil (Bartnikowska 2008; Matthaus \& Bruhl 2008; Matthaus \& Spender 2008; Przysławski \& Boleslawska 2006). Cold-pressed oil has nutritionally valuable food components like tocopherols, sterols, carotenoids, phospholipids with oxidative properties which partly get exposed from refined oils or destroyed during the refining process (Wroniak \& Krygier 2006). 
The quality requirements imposed both by the oil industry and more health-conscious consumers continue to increasing trends force the oil producers to improve their technology. It is achieved through the application of the most advanced technologies in different fields in order to obtain fats with the best health, nutritional and utilitarian attributes. Moreover, the ecological and economic aspects of fat production have been emphasized by Płatek (2004). The traditional wet extraction methods used by rural communities is regarded as inefficient in terms of oil recovery and oil yield which is below the range of plant oil content found in the literature (Alonge \& Olaniyan 2006; Olaniyan 2010).

Ali et al. (2005) described that conventional methods, namely solvent extraction and mechanical expression are the well-known and widely practiced methods of oil extraction. Most of the seed oils are extracted either by both methods or by combination of the two. This classification may also include interpreted that not as widely used. In spite of the extraction method, extracted and refined oil must be evaluated for its physico-chemical properties to determine its application or usage. The health contributing effect of functional food should be well documented with scientific research, European Commission Community Research (2000), has defined more often the consumers turn to natural food with health promoting qualities, termed functional food, if it's beyond nutritional values, proved to be therapeutic potentials on one or more of the body functions leading to health promotion and disease prevention. Attributes of conventional food and beneficial effects must

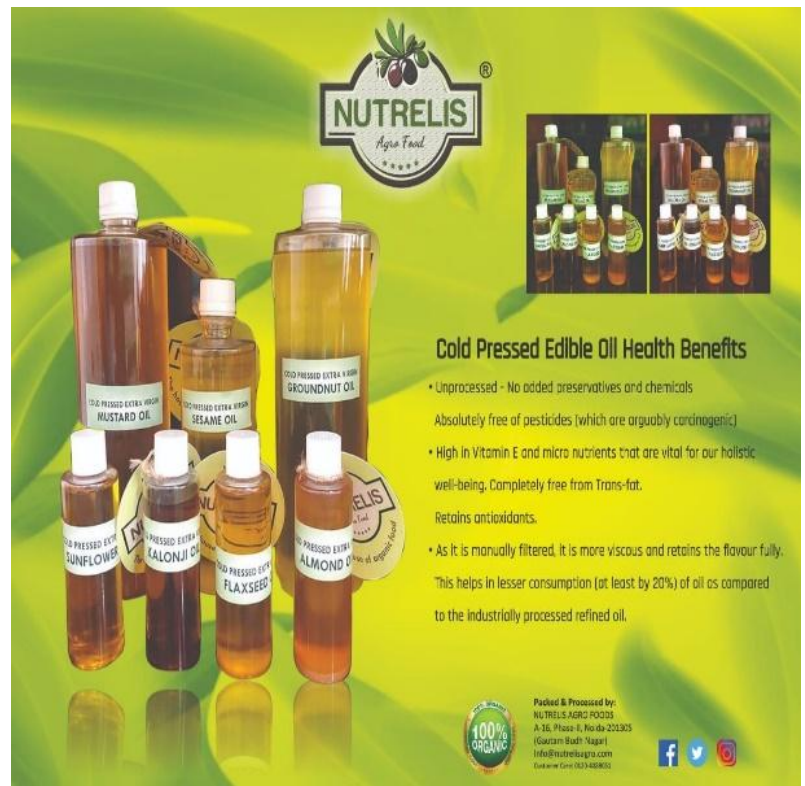

possess in functional food with values to be consumed with balance diet as an integral part of every day's diet, which neither be neither pills nor capsules.

The division of functional food was made taking into consideration its impact on physiological functions of the human body: food reducing the risk of circulatory diseases,

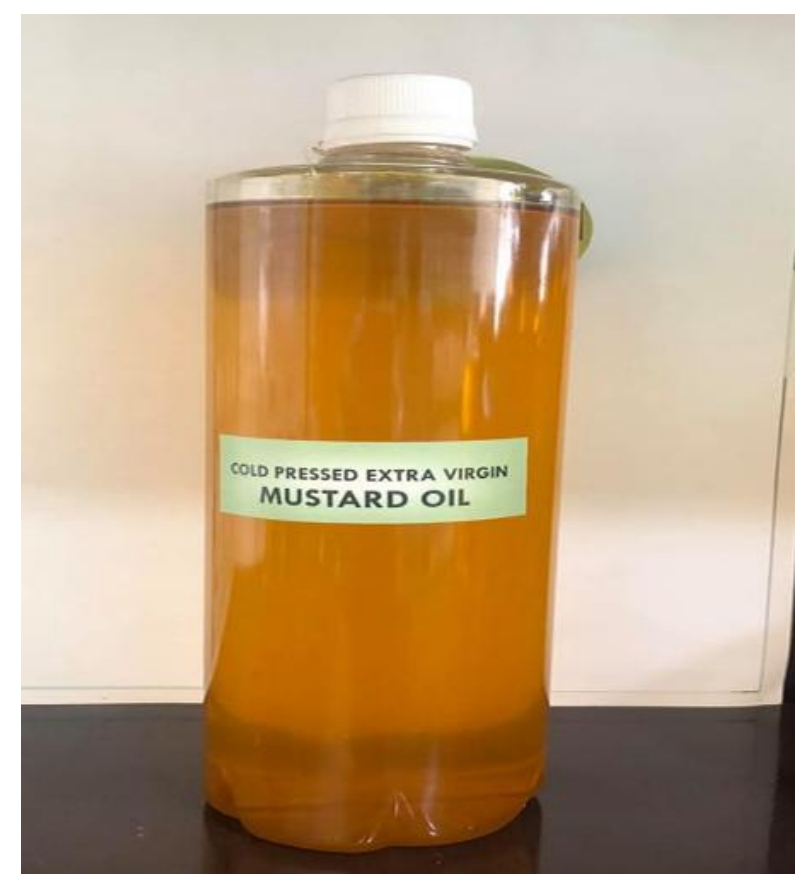


cancer and osteoporosis developments; food regulating appropriate functions of GI tract; and food aimed at combating stress-related symptoms. Besides, food was divided into the natural food rich in a particular nutrient, food enriched with health promoting components and food deprived of anti-nutritional values. More the term of functional food has been applied to the products containing n-3 polyunsaturated fatty acids (PUFA), phytosterols and fiber (Bartnikowska 2007; Ferguson \& Philipott 2008; Pieszka \& Pietrac 2010). Cold-pressed oils provide a wide range of bioactive substances, such as tocopherols and tocotrienols, free and esterified sterols, hydrocarbons (squalene), triterpene alcohols, carotenoids and chlorophylls along with colourants being valuable nutrients are called functional food. It contains n-3 and n-6 PUFA or sterols having biologically active effects (Minkowski et al. 2011; Parry et al. 2008; Schmitz \& Ecker 2008) Dzieciol \& Przysławski (2013); Sacks (2008) and Ziemlanski (1998), have demonstrated that the presence of the essential ingredients in oils is dependent on the quality, grain type and its varieties which may serve as a functional food. The health beneficial capacities and practical applications of oil is determined by their chemical composition. It has been found that the rapid intake of these oils can result in obstruction of diseases, like, ischemic heart disease (IHD), obesity hypertension due to presence of antioxidants like tocopherols and polyphenol compounds (significantly increased anti-oxidative properties).

\section{Properties of cold-pressed oils}

Tynek et al. (2012) have emphasized on cold-pressed oils can be valuable edible oils do not contain harmful constituents to humans and free from microbiological contamination and metals $(\mathrm{Fe}, \mathrm{Cu})$ accelerating the oxidation of oils and chlorophylls usually removed during the refining process. Recent technology of obtaining oils through coldpressing using nitrogen atmosphere or supercritical carbon dioxide extraction allows retaining them almost in an intact state. Their chemical composition is richer in by-products with a higher level of biological and antioxidating activity. The presence of antioxidants inhibiting deleterious changes and an insight into their activity and stability is of paramount importance not only for food technologists but also for nutritionists (Minkowski 2008). Apart from the coldpressing parameters, the technological attributes of raw material play a crucial role in obtaining the final quality of these oils. The cold-pressed oils can be produced from grains (including seeds), fruit, nuts or germs. Special consideration should be given to Cold-pressed rapeseed oil. In spite of modest market share of cold pressed oils, they are gaining more popularity day by dayamong consumers who prefer natural, traditional and low processed food. In certain European Countries like Poland, Germany, Switzerland, Austria and Great Britain, cold-pressed rapeseed oil has grown in popularity as it possesses characteristic taste with a hint of nuts, distinct aroma and intensive colour (Wroniak 2012). The cold-pressed rapeseed oil in contrast to the refined one is less resistant to oxidation, unlike olive oil (extra virgin). The rape seeds of low quality i.e., too moist, unripe, contaminated, damaged and those already undergoing hydrolytic and oxidative changes 
result in obtaining low quality oil characterized by low oxidative stability. The most valuable in terms of sensory attributes are oils from high-quality raw materials subjected to minimum oxidative changes (Wroniak \& Krygier 2006; Wroniak 2012). Cold-pressed oils have a distinct aroma and taste. They are used both as an additive to fresh food and as an ingredient enhancing various products (e.g. bread, mayonnaise) with specific bioactive nutrients. Oxidative stability is a crucial quality marker of coldpressed oils containing natural antioxidants (carotenoids, tocopherols, sterols, phospholipids, phenol compounds, among others) as well as undesirable substances with oxidative properties (e.g. chlorophylls, metals) being removed in the refining process (Obiedzinska et al. 2012).

The appropriate measures taken to protect oils just after their extraction using various procedures such as inhibition or elimination ofoxygen in contact with oils, light, metal ions promoting oxidation $(\mathrm{Fe}, \mathrm{Cu})$ as well as the inclusion of substances which reduce oxidation processes in oils permit to extend the shelf-life. Consequently, various kinds of antioxidants are utilized. Due to many health reasons associated with synthetic antioxidants a trend towards their limited application has been observed. However, great importance is attached to the employment of natural antioxidants or their identical alternatives. Their versatile antioxidant activity may result in the auto oxidation of plant-derived oils rich in omega-3 PUFAs and while being introduced to diets they can render therapeutic effect on the human body thanks to their capacity to scavenge free radical (Minkowski
2008). Wroniak and Lukasik (2006) in their study demonstrated that cold-pressed sunflower and rapeseed oils and their refined counterparts did not produce statistically significant differences in terms of their stability in the Rancimat test. On the contrary, the differences between cold-pressed soybean oil and extra virgin olive oil and refined oils were statistically significant. The extra virgin olive oil was characterized by the longest induction time and the sequence of other oils was as follows: refined rapeseed oil, coldpressed soybean, cold-pressed rapeseed oil, refined olive oil, refined soybean oil, refined and cold-pressed sunflower oil.

\section{Production of cold-pressed oil}

Cold-pressed oils are extracted from seeds and fruit of oil bearing plants having more than $15 \%$ oil content. The exception is the oil extracted from amaranthus seeds whose fat content is $4.9-8.1 \%$. Thequality attributes of oils or plant-derived fats are greatly affected by plant taxonomy andclassification. Based on type of raw material and botanic classification oilscan be obtained from seeds (e.g. canola, flax, poppy, borage, hippophae or sea-buckthorns, pumpkin, blackcurrant, grapes), fruit (e.g. plums, hippophae or seabuckthorns), nuts or kernels (e.g. hazel, walnuts, argan) or sprouted grains (e.g. wheat germs) (Obiedzinska 2012). Cold-pressing is one of the most ancient natural ways of oil extraction. This method is generally recognized as safe (GRAS) since no solvents are used. It is performed using hydraulic or expeller (screw-type) press equipped with a cooling system. This method is relatively easy and inexpensive. 


\section{Stages of cold pressing}

Seed defatting: It enables to obtain a better quality of oils (brighter colour, higher oxidative stability) and meal, though it is not used on an industrial scale due to some technical difficulties. This process improves the oil quality by reducing the content of chlorophylls and other substances such as metals, pesticides permeating through the hulls or shells into the oil.

Seed fragmentation (crushing): It permits to extract the oil by partial destruction of the seed structure and hull, opening some cells, enlarging the oil spillage area and lowering the cell resistance. Crushed seeds should immediately be subjected to further processing as the quality and stability of coldpressed oil is time-dependent.

Seed conditioning: Roasting in the ovens by exposing the pulp to the temperature of approx. $100^{\circ} \mathrm{C}$ and if necessary moisturizing it to the optimal humidity. This treatment positively affects oil extraction; however, it negatively influences the oil and meal quality. The high quality of cold-pressed oils is affected by many factors. It is utmost importance the raw material quality i.e. purity, uniformity, integrity and ripeness. Harvest time is another key determinant. In addition, the raw material quality is impacted by pre-pressing activities including crop gathering, drying, storage and post-harvest handling.

Studies were conducted on coldpressed oils extracted in the hydraulic press indicated that the only advantage of whole seed conditioning (roasting) before extrusion was a reduced level of lipid hydrolysis i.e. no significant changes in acid value in proportion to milled seeds. They suggested seed milling and application of conditioning temperature at $60-80^{\circ} \mathrm{C}$ in order to obtain the optimal oil quality and cause desirable changes (an increase in extraction yield and oxidative stability) while reducing the negative trends in taste deterioration, elevated acid and peroxide value and higher amount of pigments. Based on the findings it was discovered that in screw-type press used for cold pressing regardless of a nozzle diameter it was possible to extract oils in mild conditions without any changes in primary and secondary oxidation state (number) in fatty acid content and oxidative stability of the obtained oils. However, the extraction efficiency was low

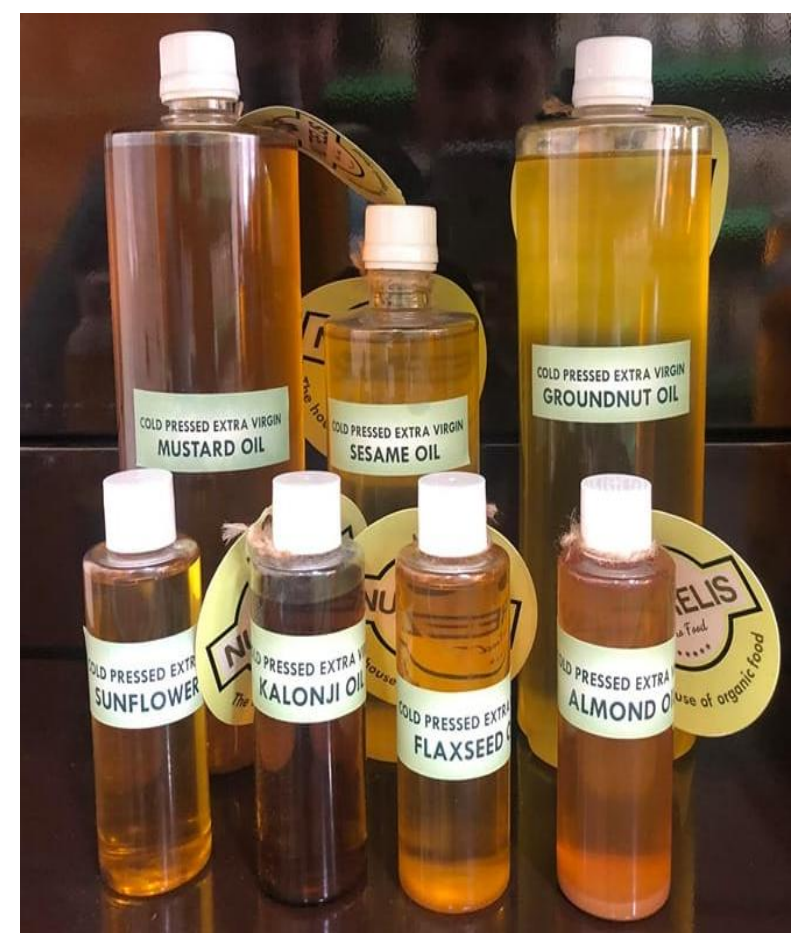

whereas the residual fat content in pomace (cake) high. Before pressing the seeds, exposing it to an elevated temperature causes a substantial increase in extraction yield in 
combination with an increase in colour darkening, lipid hydrolysis and pheophytin content.

Bioactive compounds present in coldpressed oils and their health beneficial properties. The cold pressed oils to contain triglycerides (approx.95\%) and small amount of diglycerides, monoglycerides and free fatty acids (FFA). The rest consists of non-glycerol fraction unsaponifiable matte demonstrating a wide range of quantitative and qualitative modifications. These are phospholipids, tocopherols and tocotrienols, free and esterified sterols, hydrocarbons (squalene), triterpene alcohols, carotenoids and chlorophylls along with colour-forming compounds being valuable nutrients. The presence of these components is dependent on raw material quality, plant genotype along with climatic conditions of growth and cultivation techniques used. The content of fatty acids both in cold-pressed and refined oils does not change drastically whereas the content of non-glycerol fraction is reduced. During the chemical refining process, the unsaponifiable matter is partly removed e.g. tocopherols, sterols or polyphenolic compounds.

Table 1. Presents bioactive compounds present in the selected cold-pressed oils

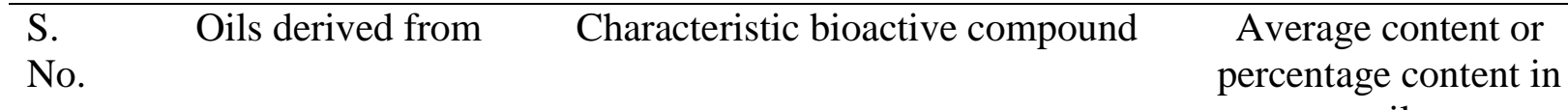

oil

1. Olive oil

2. Rapeseeds

3. Flax seeds

4. Camelina seeds

5. Eveningprimrose seeds

6. Borage seeds

7. Raspberryseeds

8. $\quad$ Grape seeds

9. Amaranthus seeds

\section{Oleic acid (n-9) \\ Brassicasterol, Plastochromanol-8 \\ $\alpha$ - linolenic acid linoleic acid plastochromanol-8 Sterols Carotenoids}

linoleic acid eicosenic acid Tocopherols Sterols Carotenoids

$$
\begin{gathered}
\alpha-\text { linolenic acid } \\
\text { linoleic acid } \\
\alpha \text { - linolenic acid } \\
\text { Tocopherols } \\
\text { Chlorophylls }
\end{gathered}
$$

$\alpha$ - linolenic acid

linolenic acid

Squalene
55- $83 \%$

$104 \mathrm{mg} / 100 \mathrm{~g}$ $55-80 \mathrm{mg} / 100 \mathrm{~g}$

51.8- $60.4 \%$

$34.8-55.3 \mathrm{mg} / \mathrm{kg}$

$15.2-17.4 \%$

$475.4 \mathrm{mg} / 100 \mathrm{~g}$ $147.5 \mathrm{mg} / \mathrm{kg}$

$$
\begin{gathered}
30-40 \% \\
15 \% \\
713.6 \mathrm{mg} / \mathrm{kg} \\
510.9 \mathrm{mg} / 100 \mathrm{~g} \\
160.1 \mathrm{mg} / \mathrm{kg} \\
8-14 \% \\
70-75 \% \\
16-27 \% \\
1410.2 \mathrm{mg} / \mathrm{kg} \\
2.8 \mathrm{mg} / \mathrm{kg} \\
29.1-32.4 \% \\
50.1-77.8 \% \\
6-8 \%
\end{gathered}
$$




\begin{tabular}{llcc} 
10. & Pumpkin seeds & Squalene & $0.9 \%$ \\
11. & Rice bran & $\gamma$ - oryzanol & $1.5-2.9 \%$ \\
12. & Sesame seeds & sesamin & $0.5-1.1 \%$ \\
\hline
\end{tabular}

Thus cold-pressed oil exhibiting
nutritionally desirable omega-6/omega-3 ratio (reaching 2.3) is rapeseed oil. Cold-pressed oils did not show any presence of trans fatty acid isomers, whereas in refined oils subjected to refining and deodorizing processes these isomers occurred at approx. $1 \%$. The current studies conducted in the oil processing sector are aimed at obtaining technology that guarantees the production of high quality and health enhancing oilwith low level wastes harmful to the natural environment, improved raw material and byproduct utilization and better energyefficiency.

\section{Conclusions}

Cold-pressed oils have been accepted as a functional food due to the presence of bioactive substances. The content of EFAs, sterols or tocopherols may prevent or retard the lifestyle diseases such as cardiovascular diseases, cancer, and obesity or have antiageing properties. Recently, numerous studies have been undertaken to evaluate the nutritional values of various cold-pressed oils. Chemical composition of cold-pressed oils determines their health contributing potential and their application. The ingestion of coldpressed oils should be appropriate in order to balance the intake of omega-6 and -3 PUFAs.

\section{Acknowledgement}

Authors are thankful to Dr MMV Baig, Professor, Yashwant College, Nanded, for encouragement and support for conducting this work and also thankful for Pradeep Dwivedi And Mr Dhreej Madan for providing
Laboratory facility at Nutrelis Foods, Noida and special thanks to Ms Anjali Singh, Ms Susmita Ranjan and Ms Shivani Sadani Research and development team members of Nutrelis Agro foods.

\section{References}

Ali FM, Ali BE \& Speight JG. 2005. Handbook of industrial chemistry: organic chemicals. McGraw- Hill Education, USA.

Bartnikowska E. 2007. Effect of phytosterols on lipids methbolism. Tłuszcze Jadalne (Edible Fats), 42, 12-29 (in Polish).

Bartnikowska E. 2008. The physiological activities of polyunsaturated fatty acids of the n-3. Tłuszcze Jadalne (Edible Fats), 43(1/2) 10-15 (in Polish).

Dzięciol M \& Przysławski J. (2013. Assessment of the nutritional and biological activity of selected vegetable oils available on the Polish market in the context of prevention of diet-related diseases, Bromat. Chem. Toksykol. XLVI, 1, 20-26 (in Polish).

European Commission Community Research. 2000. Project Report: Functional food science in Europe, Volume 1; Functional food science in Europe, Volume 2; scientific concepts of functional foods in Europe, Volume 3. EUR-18591, Office for Official Publications of the European Communities, L-2985, Luxembourg.

Ferguson LR \& Philipott M.2008. Nutrition and mutagenesis. Annual Rev. Nutr., 28: 313-329. 
Matthaus B \& Bruhl L. 2008. Why is it so difficult to produce high-quality virgin rapeseed oil for human consumption? Eur. J. Lipid Sci. Technol., 110: 611617.

Matthaus B \& Spender F. 2008. What we know and what we should know about virgin oils - a general introduction. Eur. J. Lipid Sci. Technol., 110, 597-601.

Minkowski K, Grzeskiewicz S. \& Jerzewska M. 2011. Assessment of nutritive value of plant oils with high content of linolenic acids based on the composition of fatty acids, tocopherols, and sterols. Żywnosc. Nauka. Technologia. Jakosc (Zywnosc), 2 (75): 124-135.

Minkowski K. 2008. Studies on the oxidative stability of vegetable oils rich in polyene fatty acids with trienes structure. Rozprawa habilitacyjna. Roczniki IMPiT, tom XLVI/4.

Mińkowski K. 2008. Studies on the oxidative stability of vegetable oils rich in polyene fatty acids with trienes structure. Rozprawa habilitacyjna. Roczniki IMPiT, tom XLVI/4.

Obiedzinska A \& Waszkiewicz-Robak B. 2012. Cold-pressed oils as functional food. Żywnosc. Nauka. Technologia. Jakosc (Zywnosc), 1 (80): 27-44.

Obiedzinska A. \& Waszkiewicz-Robak B. 2012. Cold-pressed oils as functional food. Zywnosc. Nauka. Technologia. Jakosc (Zywnosc),1 (80): 27-44.

Parry JW, Cheng Z, Moore J \& Yu LL. 2008. Fatty acid composition, antioxidant properties, and antiproliferative capacity of selected cold-pressed seed flours. $J$. Am. Oil Chem. Soc., 85: 457-464.
Pieszka M \& Pietrac M. 2010. Nowe kierunki w badaniach żywieniowych nutrigenomika (New directions in clinical nutrition - nutrigenomics). Rocz. Nauk. Zoot., 37 ( 2): 83-103.

Płatek T. 2004. Current trends and tendencies in studies of fats (Edible Fats), t.XXXIX, 1/2, - 3/4, 189-201 (in Polish).

Przysławski J., Bolesławska I. (2006) Dietary fats - a therapeutic or pathogenic agent. Tłuszcze Jadalne (Edible Fats), 41, (3/4), 179-192 (in Polish).

Sacks F. 2008. The Nutrition Source. Ask the Expert: Omega-3 Fatty Acids., http://www.hsph.harvard.edu/nutritionso urce/questions/omega-3/.

Schmitz G. \& Ecker J. 2008. The opposing effects of n-3 and n-6 fatty acids, Progress in Lipid Research, Elsevier Ltd., doi:10.1016/j.plipres.2007.12.004.

Tynek M, Pawłowicz R, Gromadzka J, Tylingo R., Wardecki W \& Karlovits G. 2012. Virgin rapeseed oils obtained from different rape varieties by cold pressed method-their characteristics, properties and differences. Eur. J. Lipid Sci. Technol., 114: 357-366.

Wroniak M \& Krygier K. 2006. Oleje tloczone na zimno (Cold-pressed oils). Przemysł Spozywczy (Food Industry), 7 , 30-34 (in Polish).

Wroniak M, Lukasik D. \& Maszewska M. 2006.) Porownanie stabilnosci oksydatywnej wybranych olejow tloczonych na zimno $\mathrm{z}$ olejami rafinowanymi (Comparison of oxidative stability of selected cold-pressed oils with refined oils) Żywnosc. Nauka. 
Technologia. Jakosc (Zywnosc), 1 (46): $214-221$.

Wroniak M. \& Krygier K. 2006. Cold-pressed oils. Przemysł Spożywczy (Food Industry), 7: 30-34.

Wroniak M. 2012. Nutritional value of coldpressed rapeseed oils. Zywnosc. Nauka.
Technologia. Jakosc (Zywnosc), 6 (85): 79-92.

Ziemlanski S. 1998. The physiological role of fatty acids $n-6$ and $n-3$ in the human body with particular emphasis on prevention of civilization metabolic diseases, 11-20. 